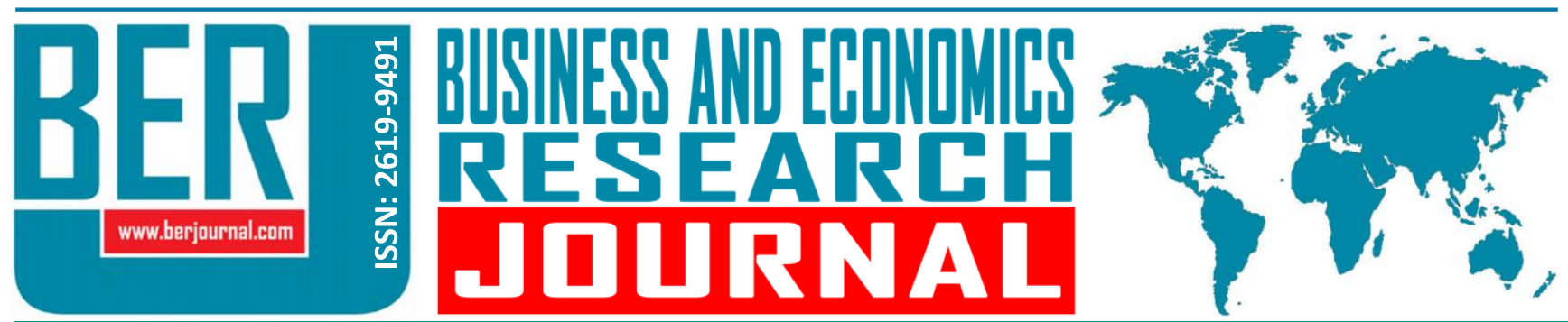

Business and Economics Research Journal Vol. 9, No. 4, 2018, pp. 911-922 doi: 10.20409/berj.2018.147

\title{
Uluslararasılaşma Sürecinin Başlamasında "Ağ Oluşturma Mekanizmaları"
}

\author{
Cigdem Baskici ${ }^{a}$, Yavuz Ercil ${ }^{b}$
}

Öz: Çalışmamızda Türkiye'deki işletmelerin uluslararasılaşmada kullandıkları ağ oluşturma mekanizmalarının ortaya çıkarılması hedeflenmektedir. Bu amaçla 01.01.2018-30.03.2018 tarihleri arasında Ankara ilinden ihracat belgesi alan küçük ve orta ölçekli ișletmeler üzerine nicel bir araștırma gerçekleştirilmiştir. Çeşitli sektörlerde faaliyet gösteren 90 işletmeden elde edilen bulgular işletmelerin uluslararasılaşmada temelde 3 tür ağ oluşturma mekanizmasından yararlandıklarını ortaya koymaktadır. İşletmelerin büyük çoğunluğu $(\% 52,2)$ stratejik olarak kendileri tarafından oluşturulan ağları kullanmaktadır. Bu durum işletmelerin uluslararasılaşmaya yönelik aktif bir şekilde ă̆ olușturabildikleri şeklinde yorumlanabilir. Diğer iki yaygın ağ oluşturma mekanizması ise mevcut tanıdıklar ile olan sosyal iliş̧ileri $(\% 23,3)$ ve mevcut müşteriler/tedarikçiler ile olan iş ilişkilerini $(\% 13,3)$ kullanmak olmuștur. ișletmeler arasında, kamu kurumlarının destekleriyle olușturulabilecek potansiyel ağları kullanmaya yönelik eğilimin çok az olduğu tespit edilmiştir. Bununla birlikte işletmeler, uluslararasılaşmada kullanacakları ağları oluştururken çatı örgütlerinin olası katkılarından hiç yararlanmamaktadır. Kamu kurumlarının ve çatı örgütlerinin ihracata yönelik desteklerini yoğun bir şekilde sürdürmelerine rağmen böyle bir durum, işletmelerin sunulan desteklere yönelik yeterli düzeyde bilgi sahibi olmadığının bir sonucu olarak görülebilir. Elde edilen bulgular hem karar vericiler olarak işletmeler hem de politika yapıcıları olarak kamu kurumları ve çatı örgütleri için çeşitli önerilerin geliştirilmesini mümkün kılmaktadır.

\section{"Networking Mechanisms" at the Beginning of the Internationalization Process}

\begin{abstract}
In our study, the networking mechanisms that the Turkish companies use for internationalization is aimed to reveal. For this purpose, a quantitative research has been carried out on small and medium sized companies that have export certificates from Ankara between 01.01.201830.03.2018. Findings from 90 companies operating in various sectors reveal that firms mainly benefit from 3 types of networking mechanisms in internationalization. The vast majority of companies (52.2\%) use the networks that they strategically formed. This can be interpreted that companies can form network for internationalization actively. The other two widespread networking mechanisms are using social relationships with current acquaintance (23.3\%) and business relationships with existing customers/suppliers (13.3\%). A little tendency of using networks that could be created with the support of public institutions is determined among the companies. Nevertheless, companies do not use the possible contributions of umbrella organizations in forming networks for internationalization. Although public institutions and umbrella organizations intensively pursue their support for exporting, such a situation can be seen as a result of the fact that companies do not have sufficient knowledge of the support provided. The findings make it possible for companies as the decision makers, and public institutions and professional organizations as policy makers to develop various suggestions.
\end{abstract}

\section{Anahtar Sözcükler:}

Uluslararasılaşma Süreci, Uluslararası Yönetim, Uluslararasılaşma Stratejisi, Ağ Iliş̧ileri, Ağ Oluşturma

JEL: M10, M16, L21, D85, L14

$\begin{array}{ll}\text { Geliş } & : \text { 24 Mayıs } 2018 \\ \text { Düzeltme } & : \text { 10 Temmuz } 2018 \\ \text { Kabul } & : \text { 25 Temmuz 2018 } \\ \text { Tür } & : \text { Araştırma }\end{array}$

Keywords:

Internationalization Process, International Management, Internationalization Strategy, Network Relations, Networking

JEL: M10, M16, L21, D85, L14

Received : 24 May 2018

Revised : : 10 July 2018

Accepted : 25 July 2018

Type : Research

a Asst. Prof., Ph.D., Başkent University, Faculty of Health Sciences, Ankara, Turkiye, cbaskici@baskent.edu.tr (ORCID ID: 00000003-0712-1481)

b Prof., PhD., Başkent University, Faculty of Communication, Ankara, Turkiye, yercil@baskent.edu.tr (ORCID ID: 0000-0003-20167329) 


\section{Giriş}

Uluslararasılaşma bir işletme için hem rekabetçi güç hem de sürdürülebilir büyüme açısından çok önemli bir hamledir. Bu kadar kritik bir süreçte işletmenin örneğin ihracat veya doğrudan yatırım kararı stratejisini belirleyen/harekete geçiren nedir? Bu soruya çok çeşitli açılardan yanıt verilmesi mümkündür. İşletmeye özel kaynakların stratejiyi harekete geçirdiğini iddia eden kaynak-temelli yaklaşım (Barney, 1991; Teece, Pisano ve Shuen, 1997) işletme varlıklarının dışarı doğrudan yabancı yatırım ve ihracat davranışını nasıl etkilediği ile ilgili değerli kavrayışlar sağlamaktadır (Wang, Hong, Kafouros, Wright ve 2012: 655). Her işletme sahip olduğu somut ve soyut varlıkları ve kabiliyetleri doğrultusunda uluslararası pazarlarda kendisine pozisyon yaratmaktadır. Örneğin kaynak kıtlığı işletmenin uluslararasılaşmanın ileri aşamalarına geçmesini engellerken (Laufs ve Schwens, 2014) sosyal sermayenin varlığı işletmenin uluslararasılaşmasını kolaylaştırabilmektedir (Gittins, Lang ve Sass, 2015; Lindstrand ve Hånell, 2017; Yli-Renko, Autio ve Tontti, 2002).

İşletme kaynakları içinde görülmeye başlanan ağların (Freeman, Edwards ve Schroder, 2006; Udomkit ve Schreier, 2017) işletmelerin uluslararasılaşmasındaki önemi uzun yıllardır vurgulanmaktadır. Sahip oldukları benzersiz ve kendine has ağ örüntüleri işletmelerin uluslararası pazarlara yönelik yeni fikirlere, bilgilere ve fırsatlara farklı biçimlerde maruz kalmasına neden olmaktadır (McEvily ve Zaheer, 1999). Böylece işletmeler arasında, sahip oldukları ağların niteliklerine göre uluslararasılaşma süreçlerinde/stratejilerinde farklılıklar ortaya çıkabilmektedir.

Türkiye'deki işletmelerin uluslararasılaşması yerel literatürde çeşitli açılardan ele alınmıştır (bk. Akben, 2014; Altıntaş \& Özdemir, 2006; Beğendik, 2017; Kalyoncuoğlu \& Üner, 2010; Kanat, 2016; Şahin, Mert, \& Kaplan, 2015). Ağlar, özellikle küçük ve orta ölçekli işletmelerin uluslararasılaşmasında belirleyici olarak görülmekle beraber (Batas ve Liu, 2013; Coviello, 2006; Coviello ve Martin, 1999; Zain ve Ng, 2006) Türkiye'deki işletmelerin uluslararasılaşmanın ilk aşamasında hangi ağları tercih ettiklerine yönelik net bir cevap yoktur. Bu çalışmada işletmelerin uluslararasılaşmada ağ oluşturma mekanizmalarının neler olduğu araştırılmıs ve uluslararasılaşmanın göstergesi olarak ihracat kullanılmıştır. Çalışma 01.01.2018-30.03.2018 tarihleri arasında Ankara ilinden ihracat belgesi alan küçük ve orta ölçekli işletmeler üzerinde nicel bir araştırma olarak tasarlanmıştır.

Makale işletme ağlarının uluslararasılaşmayı nasıl ve hangi yollarla etkilediğini tartıştığımız bölümle devam etmektedir. Sonrasında veri kaynağının tanımlandığı ve veri toplama sürecinin anlatıldığı kısım yer almaktadır. Bulgular kısmında analiz sonuçları sunulmuştur. Son bölümde ulaşılan sonuçlara, çalışmanın kısıtlılıklarına ve gelecek çalışmalarla ilgili çeşitli önerilere yer verilmektedir.

\section{Ağ iliş̧kileri ve Uluslararasılaşma}

Son dönemlerde, ilişkiler seti olarak ağlar işletmelerin uluslararasılaşmasında gereksinim duyduğu önemli bir kaynak haline gelmiştir (Kontinen ve Ojala, 2011). Ayrıca işletmelerin uluslararasılaşma niyetini harekete geçirip onları bu konuda motive etmektedir (Sharma ve Johanson, 1987; Zain ve Ng, 2006). Ağ "bireyleri, kurumları veya ülkeleri içeren birimler setidir ve birimlerin ne dereceye kadar, nasıl ve hangi açılardan birbirlerine bağlı olduğunu" tanımlamaktadır (Maoz, 2011: 7). Aktörler arasındaki bağlantılar kaynakların akışı için kanallar oluşturur (Wasserman ve Faust, 1994) ve bu aktörler bilgi ve kaynak paylaşarak ilişkilerini şekillendirirler (Pescosolido, 2007: 210-211). Aktörler arasındaki ilişki türünün niteliği, aktörlerin ulaşabileceği kaynağın hem derinliğini hem çeşitliliğini belirlemektedir (Lechner ve Dowling, 2003: 3). Granovetter (1973) zayıf bağların gücü teorisinde yeni bilgiye ulaşmada zayıf bağların güçlü bağlara kıyasla daha önemli bir role sahip olduğunu kurumsallaştırmaktadır. Çünkü güçlü bağlar herkesin aynı şeyi bildiği küçük gruplar içinde ortaya çıkarken zayıf bağlar bağlantısız grup ve bireyleri birbirine bağlamaktadır (Hansen, 1999: 82). Diğer bir ifade ile zayıf bağlar köprüdür ve yeni bilginin potansiyel kaynaklarıdır. Bu da zayıf bağların benzersiz bilgi avantajı yaratabileceğini ima etmektedir. Bununla birlikte güçlü bağlar çok az bilgi çeşitliliği sağlamasına rağmen derin bilginin de kaynağıdır (Lechner ve Dowling, 2003: 3) ve güvenle ilişkilidir (Rowley, Behrens ve Krackhardt, 2000: 369). Yeni bilginin kaynağı ile ilgili bir diğer teori (Burt, 1992) yapısal boşluk teorisidir. Teoride kritik olan ilişkinin güçlü veya zayıf olup olmamasından bağımsız olarak ilişkinin nasıl bir ağ 
yapısı içinde olduğudur. Aktörün ikili ilişkileri yapısal boşluklar arasında olduğunda bilgi avantajı yaratabilmektedir. Esasında her iki yaklaşımın benzer şeyi söylediğini Borgatti ve Lopez-Kidwell (2014: 42) basit bir örnekle açıklamaktadır. Buna göre yapısal boşluk teorisinde aktör A aktör B'ye göre ne kadar çok yapısal boşluğa sahipse, zayıf bağların gücü teorisinde aktör $A$ aktör B'den o kadar fazla köprüye, sonuç olarak da o kadar yeni bilgiye sahiptir. Bu perspektiften bakıldığında işletmelerin uluslararasılaşma sürecinde gereksinim duyduğu yabancı pazar bilgisi her işletmenin kendi ağındaki ilişkilerin niteliğine bağlıdır.

Uluslararasılaşma literatüründe işletmelerin uluslararasılaşmada kullanabileceği farklı türlerde ağ ilişkisi tanımlanmıştır. Bunları temel olarak iki kategoriye ayırmak mümkündür: örgütler arası ağ ilişkileri (formal ağlar veya iş ağları) ve kişisel ağ ilişkileri (sosyal ağlar veya informal ağlar) (Coviello ve Martin, 1999; Coviello ve Munro, 1995; Coviello ve Munro, 1997; Ge ve Wang, 2013). İşletmelerin iş ağlarında müşteriler, tedarikçiler, iş ortakları veya rakipler (Oparaocha, 2015); sosyal ağlarında aile üyeleri ve arkadaşlar gibi aktörler yer almaktadır (Björkman ve Kock, 1995; Coviello, 2006; Ge ve Wang, 2013). İş ağları içindeki aktörler birbirlerine iş faaliyetleri ile bağlanmıştır (Forsgren, Holm ve Johanson, 2005). İ̧̧ ağı bir örgütün çevresi ile olan en önemli ara yüzüdür ve çevre ile yürütülen bilgi mübadelesi temelde iş ilişkileri aracılığıyla olmaktadır (Andersson, Forsgren ve Holm, 2001: 1061). İ̧ ilişkilerinin geliştiği ağlar, aktörler için çeşitli sebeplerden dolayı kritik öneme sahiptir. Hohenthal, Johanson ve Johanson (2014: 11) bu hususta üç önemli sebepten bahsetmektedir. Bunlardan ilki ağların işletmeler arasında ortak öğrenmenin ve enformasyon dağıtımının sistemi olmasıdır. İkincisi her aktör ağının benzersiz olması ve aktörlerin bir ağ içinde faaliyette bulunmasının yeni fırsatlar bulmak için imkanlar yaratmasıdır. Üçüncüsü ağlar aktörlere belirli bir istikrar ve öngörülebilirlik sağlamaktadır, bu da aktörler için belirsizlikleri azaltmaktadır. Ayrıca iş ilişkileri işletmelere önemli pazar kaynakları sağlamanın yanında üretim bilgisi veya pazardaki değişiklikler gibi herkesin her an ulaşamayacağı kritik pazar bilgileri de sunmaktadır (Alimadadi ve Pahlberg, 2014: 347). Sosyal ağlardaki ilişkiler ise aktörlerin sosyal bağlantılarına ve sosyal etkileşimlerine dayanmaktadır. İş ağlarından daha farklı bir niteliğe sahip olmakla birlikte karar vericiler bilgi arama faaliyetlerinde sosyal ağlarını da kullanmaktadırlar (Ellis, 2008). Ciravegna, Lopez ve Kundu (2014) Kosta Rika'dan 28 ve İtalya'dan 30 işletme üzerine yaptıkları çalışmada, işletmelerin bir kısmının yabancı pazara ilk girişlerinde mevcut iş ağlarını kullanırken bir kısmının aile üyelerini, okul arkadaşlarını, kilise üyelerini de kapsayan bir sosyal ağı kullandıklarını belirlemişlerdir.

Yabancı pazarlara ilişkin fırsatların karar vericiler tarafından fark edilmesinde hem iş hem de sosyal ağların kritik bir rol oynadığı görülmektedir (Aldrich ve Zimmer, 1986; Chandra ve Wilkinson, 2017; Coviello ve Munro, 1997; Ellis, 2008; Ge ve Wang, 2013; McDougall, Shane ve Oviatt, 1994; Oviatt ve McDougall, 2005; Singh, 2000). Ellis'in (2000) gerçekleştirdiği çalışmanın bulguları yabancı pazar fırsatlarına ilişkin bilginin sistematik biçimde pazar araştırmalarından ziyade daha yaygın olarak mevcut kişisel ilişkiler aracılığıyla edinildiğini desteklemektedir. Benzer şekilde Ellis ve Pecotich'in (2001) Avustralyalı küçük ve orta ölçekli işletmeler üzerine yaptıkları çalışmanın sonuçları karar vericilerin fırsatları sıklıkla mevcut sosyal ağları aracılığıyla öğrendiklerini ortaya koymaktadır. Bununla birlikte karar vericilerin kişisel bağlantıları ihracat başlangıcında etkili olmaktadır. Ayrıca ağ ilişkilerinin özellikle küçük ve orta ölçekli işletmelerin pazar ve pazara giriş modu seçimi üzerinde önemli etkileri olduğu iddiası çok sayıda araştırmanın (Zain ve Ng, 2006; Coviello ve Munro, 1997; Coviello ve Martin, 1999) sonucu ile uyumludur. Zain ve Ng (2006) üç Malezya yazılım işletmesinin ağ ilişkilerinin yabancı pazar seçimleri üzerindeki etkilerini araştırmışlardır. İşletmelerden birinin ilk pazarı Malezya'ya hem psişik hem de fiziksel olarak uzak olan Japonya'dır. İşletmenin Japonya'ya girişini mümkün kılan işletme yöneticisinin Japonya'da yaşayan eski bir çalışanıdır. Diğer bir işletme ise hem psişik hem de fiziksel olarak yakın olan Singapur pazarına girmeyi tercih ederken, aynı zamanda bu giriş kısmen de olsa güvendiği bir ağ üyesinin varlığı tarafından harekete geçirilmiştir. Son işletme ise sonrasında ABD'ye girebilmek için bu kararını mümkün kılacak bir pazar seçiminde bulunmuştur. Coviello ve Munro'nun (1995) çalışmasına göre yabancı pazar ve pazara giriş tercihi yalnızca işletmelerdeki yöneticilerin stratejik kararlarından değil aynı zamanda ağ bağlantıları aracılığıyla yaratılan fırsatlardan kaynaklanmaktadır.

Yukarıda bahsedildiği şekilde işletmeler mevcut iş ve sosyal ağ ilişkilerini kullanarak uluslararasılaşabilir. Bunların yanında literatürde şans eseri kurulmuş ilişkilerin işletmelerin uluslararasılaşmasına yardım edebildiği (Chandra ve Wilkinson, 2017; Ciravegna vd., 2014), işletmelerin destekleyici devlet kurumlarının yardımı ile oluşturulan ilişkiler sonucunda yabancı pazarlara girilebildiği 
(Senik, Scott-Ladd, Entrekin ve Adham, 2011; Zarei, Nasseri ve Tajeddin, 2011) veya yabancı pazardaki alıcı ile ilişki kurmasını mümkün kılacak bir üçüncü tarafla geliştirdiği aracılık ilişkisi sayesinde uluslararasılaşabildiğini gösteren çeşitli çalışmalar mevcuttur (Chetty ve Holm, 2000; Ojala, 2009; Oviatt ve McDougall, 2005; Kontinen ve Ojala, 2011).

Ellis ve Pecotich (2001) yaptıkları çalışmada küçük ve orta ölçekli işletmelerin ihracat girişimlerinin büyük çoğunlukla şansın ve tesadüfin bir sonucu olduğunu gözlemlemişlerdir. Gittins vd. (2015) çalışmalarında şansın işletmelerin uluslararasılaşmasını sağlayacak ilişkilerin kurulmasında belirli bir dereceye kadar rol aldığını belirlemişlerdir.

Aracılık ilişki türünde alıcı ve satıcı arasında doğrudan bir bağlantı olmamakla birlikte taraflar arasındaki ağ ilişkisinin kurulmasına olanak sağlayan ihracat teşvik örgütleri gibi üçüncü taraf olan bir aktör bulunmaktadır (Ojala, 2009). Kontinen ve Ojala (2011) küçük ve orta ölçekli aile işletmeleri üzerine yaptıkları çalışmada aracı ağ ilişkilerinin uluslararası fırsatların fark edilmesinde diğer ağ ilişkilerine göre daha önemli bir kaynak olduğunu bulmuşlardır. Chetty ve Holm (2000) çalışmalarında aracılarla kurulan ilişkilerin işletmelerin uluslararasılaşmasında bir sıçrama yarattığını ortaya çıkarmışlardır. O'Gorman ve Evers (2011) çalışmalarında ihracat teşvik örgütünün İrlanda'nın çevre bölgelerdeki yeni yatırımların uluslararasılaşmasını nasıl etkileyebileceğini araştırmışlardır. İhracat teşvik örgütünün işletmelerin; onlar için uluslararası fırsatları ve müşterileri belirleme, onların uluslararası müşterilere tanııımasını kolaylaştırma, ihracat kapasitelerini geliştirme konusunda kaynak sağlama ve onlara yabancı pazar bilgisi sağlama yoluyla uluslararasılaşmasını etkilediğini bulmuşlardır.

Destekleyici devlet kurumlarının uluslararasılaşma üzerindeki etkileri çeşitli ampirik çalışmalara konu olmuştur. Senik, Isa, Scott-Ladd ve Entrekin (2010) Malezyalı küçük ve orta ölçekli işletmelerde uluslararasılaşmayı etkileyen faktörleri araştırmışlardır. Çalışmaya göre uluslararasılaşmadaki en etkili unsur işletmelerin ağlarıdır ve bunların içinde de destekleyici devlet kurumları en önemli ağ olarak belirlenmiştir. Senik vd. (2011) destekleyici devlet kurumlarının küçük ve orta ölçekli işletmelerin uluslararasılaşmada ihtiyaç duydukları ağ sürecini kolaylaştırmada kritik bir rol oynadığını tespit etmişlerdir.

Bütün bu sonuçlar ağların işletmelerin uluslararasılaşma süreci üzerindeki etkisini açık bir şekilde ortaya çıkarmaktadır. Ağ, işletmelerin uluslararasılaşma sürecini başlatmasında ve sürdürmesinde kritik bir rol oynamanın yanı sıra uluslararası fırsatlara ilişkin farkındalık yaratarak ne zaman ve nasıl uluslararasılaşılacağı konusunda da yol göstermektedir (Udomkit ve Schreier, 2017). Sharma ve Johanson (1987) bu durumu ağların işletmeler için yabancı pazarlar için köprü haline gelebileceğini on yıllar önce söyleyerek etkili bir biçimde özetlemişlerdir.

\section{Yöntem}

Türkiye'deki işletmelerin uluslararasılaşmada kullandıkları ağ oluşturma mekanizmalarının ortaya çıkarılmasının hedeflendiği çalışmamızda tanımlayıcı araştırma modeli kullanılmıştır. Çalışmanın evrenini 01.01.2018-30.03.2018 tarihleri arasında Ankara ilinden ihracat belgesi alan 400 küçük ve orta ölçekli işletme oluşturmaktadır. Bu işletmeler imalat, bilişim, enerji gibi çeşitli sektörleri temsil etmektedir. Araştırmada veri toplama aracı olarak iki bölümden oluşan bir anket kullanılmıştır. Anket formu uygulanmadan önce anketin uygunluğu ve anlaşılabilirliği uzman görüşü ile desteklenmiş, gerekli düzenlemeler yapılmıştır. Formun ilk kısmında işletmenin faaliyet alanı, ihracata başladığı yıl, ilk ihracatını gerçekleştirdiği ülke gibi genel istatistiklere yer verilirken ikinci kısımda işletmelerin ilk ihracatlarında hangi ağları kullandıklarını ortaya çıkarmaya yönelik sorular bulunmaktadır. İkinci kısımdaki sorular Ciravegna ve diğerlerinin (2014) işletmelerin ilk ihracatları için ağ oluşturma mekanizmalarını araştırdıkları çalışmanın sonuçlarına dayanmaktadır. Literatür taramasından (Senik vd., 2010; Senik vd., 2011; Ojala, 2009; Kontinen ve Ojala, 2011; Chetty ve Holm, 2000; Ellis ve Pecotich, 2001) elde edilen uluslararasılaşmadaki ağ oluşturma mekanizmaları da bu sorulara eklenmiştir. Anketler 01.04.2018-13.04.2018 tarihleri arasında elektronik posta ile işletmelere gönderilmiştir. İlk ihracat deneyimleri araştırıldığı için anketler kurucular tarafından cevaplandırılmıştır. Cevap verme oranını artırmak için anket soruları üç kez gönderilmiş ve toplamda 92 anket elde edilmiş, eksik cevaplardan dolayı anketlerin 90'ı kullanılabilmiştir. 


\section{Bulgular}

Çalışmaya dahil edilen işletmelerin kuruluştan itibaren kaç yıl içinde ihracata başladıkları Tablo 1'de sunulmaktadır. Buna göre işletmelerin \%41,1'i kuruluşlarından itibaren 3 yıl içinde, \%13,3'ü 4-7 yıl, \%15,6'sı 8-11 yıl, \%11,1'i 12-15 yıl sonra ve \%18,9'u 16 yıl ve sonrasında ihracata başlamıştır.

Tablo 1. Ihracata Başlama Zamanlarına Göre İşletme Sayıları

\begin{tabular}{|l|c|c|}
\hline $\begin{array}{l}\text { Kuruluştan sonra ihracat } \\
\text { yapılan ilk yıl }\end{array}$ & $\begin{array}{c}\text { ihracat yapan işletme } \\
\text { sayısı }\end{array}$ & Yüzde (\%) \\
\hline $\mathbf{0 - 3}$ & 37 & 41,1 \\
\hline $\mathbf{4 - 7}$ & 12 & 13,3 \\
\hline $\mathbf{8 - 1 1}$ & 14 & 15,6 \\
\hline $\mathbf{1 2 - 1 5}$ & 10 & 11,1 \\
\hline $\mathbf{1 6 -}$ & 17 & 18,9 \\
\hline Toplam & 90 & 100 \\
\hline
\end{tabular}

Literatürde küresel doğanlara yönelik çok çeşitli tanımlamalar yapılmıştır. Çavuşgil, Knight ve Üner (2011: 13) Türkiye'deki küresel doğan işletmeler üzerine yaptıkları çalışmada küresel doğanları 'kuruluşlarını izleyen birkaç yıl içerisinde mal ve hizmetlerinin ihracatına başlayan ve toplam üretimlerinin $1 / 4$ ya da daha fazlasını ihraç edebilenler" olarak tanımlamışlardır. Andersson ve Wictor'un (2003) çalışmasında küresel doğan, satışlarının en az \%25'ini kuruluşundan itibaren 3 yıl içinde elde eden ve çeşitli ülkelerde kaynaklarının kullanımından ve çıktılarının satışından önemli rekabetçi avantaj elde etmeyi isteyen bir işletmedir. Altuntaş, Sözüer ve Semerciöz (2015) yaptıkları araştırmada bir işletmenin küresel doğan olabilmesi için işletmenin ihracat satışlarının toplam gelirleri içinde payı olarak tanımlanan ihracat yoğunluğunun en az \% 25 olması ve birden çok ülkeyle iş yapma ölçütlerini dikkate almışlardır. Cannone ve Ughetto (2014), Tabares, Alvarez ve Urbano (2015) kuruluşundan itibaren 3 yıl içinde toplam gelirinin en az \%25'ini ihracattan elde eden işletmeleri küresel doğan olarak tanımlamışlardır. Moen (2002) küresel doğanı tanımlarken işletmenin kuruluşundan kısa bir süre sonra satışlarııı \%25'ini ihracatın oluşturması şeklinde daha genel bir kriterden bahsetmektedir. Bütün bu çalışmalar küresel doğanın ne olduğuna ilişkin evrensel bir tanımın olmadığını göstermektedir. Çalışmamızda literatürde sıklıkla ortak kullanılan toplam gelirinin en az \%25'ini kuruluşundan itibaren 3 yıl içinde ihracattan elde etme koşulunu yerine getiren işletmeler "küresel doğan"; diğerleri "küresel doğmayanlar" olarak kategorize edilmiştir. Buna göre işletmelerin \%21,1'i küresel doğarken \%78,9'u küresel doğmamıştır (Tablo 2).

Tablo 2. İşletmelerin İhracata Başladıkları Yıllar İtibariyle Sınıflandırılması

\begin{tabular}{|l|c|c|c|}
\hline $\begin{array}{l}\text { Kuruluştan sonra ilk üç yılda } \\
\text { yapılan ihracat oranı }\end{array}$ & $\begin{array}{c}\text { İşletmenin } \\
\text { Sınıflandırılması }\end{array}$ & Işletme Sayısı & $\%$ \\
\hline $\mathbf{0 - 2 4}$ & Küresel Doğmayan & 71 & 78,9 \\
\hline $\mathbf{2 5}$ & Küresel Doğan & 19 & 21,1 \\
\hline
\end{tabular}

İşletmelerin uluslararasılaşmak için oluşturdukları ağ mekanizmaları literatürle uyumlu olarak araştırılmıştır (Tablo 3). Buna göre işletmeler uluslararasılaşmada en yaygın şekilde $(\% 52,2)$ stratejik olarak kendi oluşturdukları ilişkileri kullanmaktadır. İşletmelerin ihracat yapmak için başvurdukları ikinci yol ise aile üyeleri, okul arkadaşları gibi mevcut sosyal ilişkilerinden (\%23,3) faydalanmak olmuştur. İşletmeler üçüncü sırada $(\% 13,3)$ Türkiye'deki mevcut müşteri ve tedarikçileri ile olan iş ilişkilerini kullanarak uluslararası genişleme yoluna gitmiştir. Bu ağ oluşturma mekanizmalarını sırasıyla sosyal medya hesapları ile oluşturulan ilişkiler (\%5,6), şans eseri geliştirilen ilişkiler $(\% 3,3)$, kamu kurumlarının desteği ile geliştirilen ilişkiler $(\% 1,1)$ ve aracı firmalar sayesinde geliştirilen ilişkiler takip etmektedir $(\% 1,1)$. Bununla birlikte hiçbir işletme ilk ihracatında çatı örgütlerin destekleyici faaliyetlerinden yararlanmamıştır. 
Tablo 3. İşletmelerin Uluslararasılaşmada Kullandıkları Ağ Oluşturma Mekanizmaları

\begin{tabular}{|c|c|c|}
\hline Uluslararasılaşmada ağ oluşturma mekanizmaları & $\begin{array}{l}\text { İşletme } \\
\text { sayısı }\end{array}$ & $\begin{array}{l}\text { Yüzde } \\
\text { (\%) }\end{array}$ \\
\hline $\begin{array}{l}\text { Türkiye'deki mevcut müşterilerimiz-tedarikçilerimiz yurt dışındaki ilk müşterimizi bulmamıza } \\
\text { yardımcı oldu. }\end{array}$ & 12 & 13,3 \\
\hline $\begin{array}{l}\text { Şans eseri geliştirdiğimiz bağlantılar ilk ihracatımızı sağladı (örneğin tatilde veya uçakta yurt } \\
\text { dışı bağlantıları olan bir işletme sahibi ile tanışmak). }\end{array}$ & 3 & 3,3 \\
\hline $\begin{array}{l}\text { İlk ihracatımızı stratejik olarak bizim oluşturduğumuz ilişkiler sayesinde gerçekleştirdik } \\
\text { (örneğin kendi çabalarımızla çeşitli faaliyetlere, toplantılara, fuarlara yurt dışında ihracatı } \\
\text { kolaylaştıracak potansiyel ortak/müşteri bulmak için katılmak). }\end{array}$ & 47 & 52,2 \\
\hline $\begin{array}{l}\text { Mevcut tanıdıklarımız vasıtasıyla ilk ihracatımızı yaptık (örneğin aile üyeleri, okul arkadaşları, } \\
\text { önceki işlerden çalışma arkadaşları). }\end{array}$ & 21 & 23,3 \\
\hline İlk ihracatımızı ticaret veya sanayi odası gibi bir çatı örgütün aracılığıyla gerçekleştirdik. & 0 & 0 \\
\hline IIlk ihracatımızı bir kamu kurumunun (örneğin bakanlıklar) desteği ile gerçekleştirdik. & 1 & 1,1 \\
\hline IIlk ihracatımızı sosyal medya hesaplarımız aracılığıyla gerçekleştirdik. & 5 & 5,6 \\
\hline $\begin{array}{l}\text { Illk ihracatımızı alıcı ile aramızda ilişki kurulmasını sağlayan aracı bir firma sayesinde } \\
\text { gerçekleştirdik. }\end{array}$ & 1 & 1,1 \\
\hline
\end{tabular}

Çalışmaya dahil olan işletmeler ilk ihracatlarını kuruluşlarından itibaren farklı yıllarda gerçekleştirmiştir. Tablo 4'te işletmelerin ilk ihracat yılları ve ihracat için kullandıkları ilişsiler sunulmaktadır. Kuruluşlarından itibaren ilk 3 yılda ihracat yapan 39 işletmeden 22 'si $(\% 56,4)$ uluslararasılaşmada stratejik olarak kendi kurdukları ilişkileri kullanmıştır. Bununla birlikte kuruluşlarından itibaren 4-7 yıl sonra ihracat yapan işletmeler dışındaki işletmelerin de uluslararasılaşmada kullandıkları en yaygın ilişki türü stratejik olarak kendi oluşturdukları ilişkiler olmuştur. Kuruluşlarından itibaren 4-7 yıl sonra ihracata başlayan işletmeler arasında uluslararasılaşmada kullanılan en yaygın ilişki türü mevcut tanıdıkları ile olan ilişkileridir. Bu işletmeler sosyal ilişkilerini kullanarak ilk ihracatlarını yapmıştır. Sosyal medya kullanarak uluslararasılaşan 5 işletmeden 4'ü ihracata kuruluşlarından sonraki ilk 3 yılda başlamıştır.

Tablo 4. İşletmelerin îhracata Başladıkları Yıllara Göre Kullandıkları iliş̧kiler

\begin{tabular}{|c|c|c|c|c|c|c|c|c|c|c|c|c|c|c|c|}
\hline & 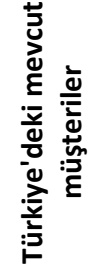 & dீ & $\begin{array}{l}\overline{\bar{d}} \\
\bar{d} \\
\bar{n} \\
\bar{w} \\
心\end{array}$ & dீ & 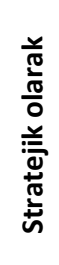 & do & 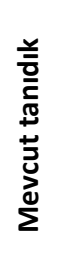 & d゚ & 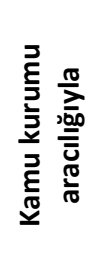 & do & 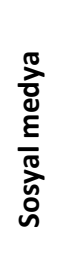 & do & 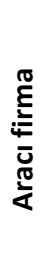 & ¿ீ & $\begin{array}{l}\frac{\varepsilon}{\sigma} \\
\frac{\pi}{0} \\
\end{array}$ \\
\hline $0-3$ & 1 & 2,6 & 0 & 0 & 22 & 56,4 & 12 & 30,8 & 0 & 0 & 4 & 10,3 & 0 & 0 & 39 \\
\hline 4-7 & 3 & 27,3 & 1 & 9,1 & 3 & 27,3 & 4 & 36,4 & 0 & 0 & 0 & 0 & 0 & 0 & 11 \\
\hline $8-11$ & 3 & 21,4 & 1 & 7,1 & 6 & 42,9 & 3 & 21,4 & 0 & 0 & 1 & 7,1 & 0 & 0 & 14 \\
\hline $12-15$ & 2 & 22,2 & 0 & 0 & 5 & 55,6 & 1 & 11,1 & 0 & 0 & 0 & 0 & 1 & 11,1 & 9 \\
\hline 16- & 3 & 17,6 & 1 & 5,9 & 11 & 64,7 & 1 & 5,9 & 1 & 5,9 & 0 & 0 & 0 & 0 & 17 \\
\hline
\end{tabular}

Küresel doğan ve küresel doğmayan işletmelerin uluslararasılaşmada kullandıkları ilişki türleri Tablo 5'teki gibidir. Küresel doğan işletmelerin uluslararasılaşmada kullandığı temel ilişki türü stratejik olarak kendilerinin oluşturdukları ilişkilerken $(\% 63,2)$ ikinci sırada mevcut tanıdıklar $(\% 31,6)$ yer almaktadır. Küresel doğmayan işletmelerin tercihleri bütün ilişki türlerini kapsamaktadır. Bununla birlikte küresel doğanlardaki gibi ilk sırada $(\% 49,3)$ stratejik ilişkiler ikinci sırada mevcut tanıdıklar $(\% 21,1)$ yer almaktadır. 
Tablo 5. Küresel Doğan ve Küresel Doğmayan İşletmelerin İlişki Tercihleri

\begin{tabular}{|c|c|c|c|c|c|c|c|c|c|c|c|c|c|c|c|}
\hline & 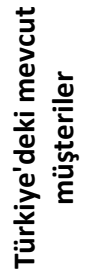 & ه̊ & 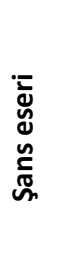 & வீ & 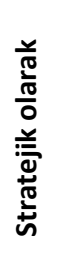 & வீ & 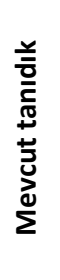 & d゚ & 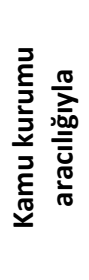 & do & 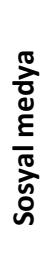 & வீ & 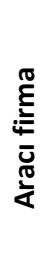 & d゚ & 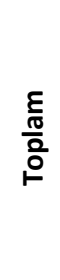 \\
\hline $\begin{array}{l}\text { Küresel } \\
\text { doğan }\end{array}$ & 0 & 0 & 0 & 0 & 12 & 63,2 & 6 & 31,6 & 0 & 0 & 1 & 5,3 & 0 & 0 & 19 \\
\hline $\begin{array}{l}\text { Küresel } \\
\text { doğmayan }\end{array}$ & 12 & 16,9 & 3 & 4,2 & 35 & 49,3 & 15 & 21,1 & 1 & 1,4 & 4 & 5,6 & 1 & 1,4 & 71 \\
\hline
\end{tabular}

Çalışma kapsamındaki işletmelerin ilk ihracat yaptıkları bölgeler arasında farklılıklar mevcuttur. Tablo 6'da ilk ihracat yapılan bölgeler ve kullanılan ilişki türleri sunulmaktadır. İlk ihracatlarını Amerika Kıtası'na yapan işletmeler uluslararasılaşmada iki ilişki türü kullanmıştır. Bunlardan ilki $(\% 66,7)$ stratejik olarak kendi kurdukları ilişkilerken ikincisi mevcut tanıdıklarıdır $(\% 33,3)$. Ilk ihracatlarını Avrupa'ya yapan işletmeler çok çeşitli ilişki türlerini kullanmakla beraber en yaygın kullandıkları stratejik olarak oluşturduklarıdır (\%60). Orta Doğu'ya ihracatta da ilk sırada stratejik olarak oluşturulan ilişkiler $(\% 52,4)$ kullanılmıştır. Asya'ya yapılan ihracatta işletmeler mevcut tanıdıkları ve stratejik olarak kendi kurdukları ilişkileri aynı oranda $(\% 37,5)$ kullanmıştır. Afrika'ya ihracat için, diğer bölgelerde olduğu gibi, en sık kullanılan ilişki türü işletmelerin stratejik olarak kendi kurduklarıdır. Kamu kurumu aracılığıyla ihracat yapılan tek bölge Avrupa olmuştur. Aracı firma kullanılarak ihracat yapılan tek bölge ise Orta Doğu'dur.

Tablo 6. Ihracat Yapılan Bölgeler ve Kullanılan İlişkiler

\begin{tabular}{|c|c|c|c|c|c|c|c|c|c|c|c|c|c|c|c|}
\hline & 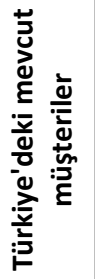 & d゚ & 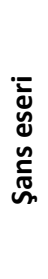 & d̊ & 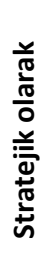 & do & 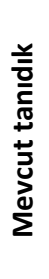 & d゚ & 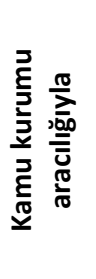 & dீ & 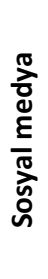 & dீ & 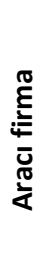 & dீ & $\begin{array}{l}\frac{\varepsilon}{\pi} \\
\frac{\pi}{2} \\
\stackrel{0}{0}\end{array}$ \\
\hline $\begin{array}{l}\text { Amerika } \\
\text { Kıtası }\end{array}$ & 0 & 0 & 0 & 0 & 2 & 66,7 & 1 & 33,3 & 0 & 0 & 0 & 0 & 0 & 0 & 3 \\
\hline Avrupa Kıtası & 3 & 10 & 1 & 3,3 & 18 & 60 & 6 & 20 & 1 & 3,3 & 1 & 3,3 & 0 & 0 & 30 \\
\hline Orta Doğu & 3 & 14,3 & 1 & 4,8 & 11 & 52,4 & 3 & 14,3 & 0 & 0 & 2 & 9,5 & 1 & 4,8 & 21 \\
\hline Asya Kıtası & 4 & 16,7 & 1 & 4,2 & 9 & 37,5 & 9 & 37,5 & 0 & 0 & 1 & 4,2 & 0 & 0 & 24 \\
\hline Afrika Kıtası & 2 & 16,7 & 0 & 0 & 7 & 58,3 & 2 & 16,7 & 0 & 0 & 1 & 8,3 & 0 & 0 & 12 \\
\hline
\end{tabular}

\section{Sonuç ve Tartışma}

İşletmelerin uluslararasılaşmada ağ oluşturma mekanizmalarının neler olduğunun araştırıldığı bu çalışmada, işletmelerin ilk ihracatlarında farklı ilişki türlerinden faydalandıkları ortaya çıkmıştır. Bulgularımız, işletmelerin ağ destekli uluslararasılaşmanın temel olarak hangi ilişki türünün sonucu olduğuyla ilgili bir genellemenin zor olabileceğinin altını çizmektedir. Bununla birlikte işletmelerin büyük çoğunluğu $(\% 52,2)$ ilk ihracatlarında stratejik olarak kendilerinin oluşturdukları ilişkileri kullanmıştır. Bu işletmeler çeşitli faaliyetlere, toplantılara ve fuarlara katılarak uluslararası genişlemeyi mümkün kılacak potansiyel müşterilerini kendileri bulmuştur. Bu durum işletmelerin aktif bir şekilde ağ oluşturabildiklerini göstermektedir. Literatürde bu tür ilişkilerin kullanılmasıyla uluslararasılaşmanın ortaya çıktığını destekleyen çalışmalar mevcuttur (Ciravegna vd., 2014). 
İşletmelerin \%23,3'ü ilk ihracatlarında mevcut tanıdıkları ile olan ilişkilerine başvurmuştur. Bu işletmelerin aile üyeleri, okul arkadaşları ve önceki işlerden çalışma arkadaşları gibi sosyal ilişkilerini yeni pazarlara ilişkin bilgi arama faaliyetlerinde kullanabildiklerini söylemek mümkündür. Bu sonuç, işletmelerin bu ilişkilerden aktif ve stratejik olarak planlanmış bir biçimde faydalandıkları şeklinde yorumlanabilir. Literatürdeki çalışmalarda da yabancı pazarlara ilişkin fırsatların ortaya çıkarılmasında mevcut kişisel ilişkilere başvurulduğuna yönelik kanıtlar mevcuttur (Ellis, 2000; Ellis ve Pecotich, 2001). Bütün bu sonuçlar sosyal ağ teorisyenlerinin yurtdışına ilişkin girişimcilik fırsatlarının bir kişinin sosyal ağından elde ettiği enformasyonlara dayanabileceği iddiaları ile tutarlıdır. Bu durum esasında karar vericilerin her zaman resmi araştırmalar sonucunda elde edilen objektif veriler doğrultusunda hareket etmediği şeklinde yorumlanabilir. Ayrıca yurtdışı pazarlara girişler araştırma maliyetlerini artıran büyük belirsizliklerle karakterize olmaktadır. Karar vericiler bu yüksek maliyetleri azaltmanın bir aracı olarak sosyal ağlarını kullanıyor olabilirler.

Işsletmelerin \%13,3'ü yurtdışındaki ilk müşterilerini mevcut iş ilişkilerini kullanarak bulmuştur. Bu sonuç, yabancı pazarlara ilişkin fırsatların karar vericiler tarafından fark edilmesinde işletmelerin mevcut iş ilişkilerini de kullandıklarını vurgulayan çalışmalar (Aldrich ve Zimmer, 1986; Chandra ve Wilkinson, 2017; Coviello ve Munro, 1997; Ge ve Wang, 2013; McDougall vd., 1994; Oviatt ve McDougall, 2005; Singh, 2000) ile uyumludur. Bu tarz ilişkilerin işletmeler arasında bilgi ve hatta teknoloji transferini kolaylaştırmasının, ilişkileri işletmeler için uluslararasılaşmada kullanılabilecek bir mekanizma haline getirdiğini söylemek mümkündür.

İşletmeler uluslararasılaşmada sosyal medyayı kullanmakla birlikte sosyal medyanın bugünün uluslararasılaşma stratejilerinin içine gömülmüş olduğu (Paniagua, Korzynski ve Mas-Tur, 2017) göz önüne alınırsa kullanımın düşük seviyelerde $(\% 5,6)$ kaldığı söylenebilir. Bu durum e-ticaret gibi yeni medya tabanlı uygulamaların işletmeler tarafından yeterince benimsenmemesinin bir sonucu şeklinde yorumlanabilir. İ̧̧letmelerin bu konuda bilinçlendirilmesi ve yetkinliklerinin artırılması konusunda çatı örgütler tarafından projeler geliştirilebilir. Bahsi geçen ilişki türlerinden daha farklı olarak işletmelerin \%3,3'ü şans eseri geliştirdikleri ilişkiler sonucunda ilk ihracatlarını yapmıştır. Bu bulgu şansın işletmelerin uluslararasılaşmasını sağlayacak ilişkilerin kurulmasında rol aldığını ortaya koyan çalışmalarla uyumludur (Ellis ve Pecotich, 2001; Gittins vd., 2015).

Elde edilen sonuçlarda dikkat çekici olan nokta işletmelerin ağ ilişkilerini oluşturmada bakanlık gibi kamu kurumlarının desteklerinden çok az yararlanması $(\% 1,1)$ ve çatı örgütlerden (sanayi ve ticaret odaları gibi) hiç faydalanmamasıdır. Türkiye Cumhuriyeti Ekonomi Bakanlığı tarafından işletmeler için ihracata yönelik devlet yardımları sağlanmaktadır. Bu yardımların temel amacı yurtdışına açılma sürecinde olan işletmelere her aşamada destek verilmesidir. Bunun yanında aynı Bakanlık tarafından "Yurt Dışında Yatııı" bilgi sayfaları oluşturulmuştur (www.ekonomi.gov.tr). Bu sayfalarda Türk işletmelerinin yatırım yapılan ülkede karşılaşabileceği çeşitli risklere yönelik tedbirler konusunda, Siyasi Risk Sigortaları ve yatırım yapılan ülkelerin yatırım ortamı hakkında bilgiye ulaşması mümkün olmaktadır. Benzer şekilde çatı örgütlerin ihracatı artırmaya yönelik yoğun çabaları söz konusudur. Bu tarz imkanların olmasına rağmen işletmelerin bunlardan yeterince faydalanmıyor olması özenle incelenmesi gereken bir durumdur. Bu davranış biçimi, sunulan desteklere yönelik işletmelerin yeterli düzeyde bilgi sahibi olmamasının bir sonucu şeklinde yorumlanabilir. Taraflar arasındaki bilgi farklılı̆ının ortadan kaldırılmasına ilişkin seminer, eğitim ve çalıştayların hazırlanması hem kamu kurumlarının hem de çatı örgütlerin ihracat desteklerinin işletmeler tarafından daha aktif şekilde kullanılmasını sağlayabilir. Yatııım yapılacak ülkelerdeki kuralları içeren bilgi ve hizmet ağı, yatırım yapılacak ülkeler ve endüstriler ile ilgi bakanlıklar ve/veya çatı örgütler tarafından hazırlanacak rehber katalogların işletmelere dağıtılması bu hizmetlere karşı farkındalığı artırabilecektir. Bununla birlikte bakanlıklar ve/veya çatı örgütleri işletmelerin ilk ihracatlarında neden kendi desteklerini veya aracılıklarını kullanmadıklarına yönelik bir araştırma yapabilir. Böylece işletmelerin ihtiyaçları ile bahsi geçen kurumların sundukları imkanların ne dereceye kadar uyuştuğunun tespit edilmesi mümkün olabilecektir. Ayrıca işletmelerin bu kurumların desteklerinden veya aracılıklarından yararlan(a)maması ihracat biriminin zayıf organizasyonu ve ihracatta uzmanlaşmış personel eksikliği ile ilgili olabilir. Diğer bir ifade ile bu durum işletmenin kendi örgütsel yapısından kaynaklanabilir. Bu tarz bir engelin ortadan kaldırılabilmesi için uluslararasılaşma konusunda hizmet içi mesleki eğitimler verilebilir. 
Işletmelerin ihracata başladıkları yıllara göre kullandıkları ilişkiler göz önüne alındığında, mevcut tanıdıklar ile olan ilişkilerinden yararlanan 21 işletmenin 12'si ilk üç yılda uluslararasılaşmıştır. Bu durum karar vericilerin pragmatik yaklaşımının bir sonucu olarak değerlendirilebilir. Mevcut tanıdıklara erişim kaynak (bilişsel ve maddi) yönetimini zorunlu kılmamaktadır. Benzer şekilde stratejik olarak kendilerinin oluşturdukları ilişkileri kullanan 47 işletmenin 22'si ilk üç yılda ulaslararasılaşmıştır. Bu kurumsal tercihi yapmayan işletmelerin ancak uzun dönemli (16 yıl sonra) deneyimleri sonucunda stratejik ağ geliştirme yetkinliğine evrildiğini görmekteyiz.

Küresel doğan ve küresel doğmayan işletmelerin ağ kurma tercihleri çeşitli açılardan farklııklar göstermektedir. Küresel doğanların $\% 63,2$ 'si stratejik olarak kendilerinin oluşturdukları ağı kullanırken, küresel doğmayanlarda bu oran $\% 49,3$ 'tür. Küresel doğanların kuruluştan itibaren yöneticilerinin ya da kurucularının sahip oldukları yönetimsel bir küresel vizyonun (Loane, Bell ve McNaughton, 2007; Oviatt ve McDougall, 2005) böyle bir sonuç doğurduğu iddia edilebilir. Çünkü küresel doğanlar kuruluşlarından itibaren kısa sürede farklı coğrafyalarda faaliyet göstermeye istekli işletmelerdir. Dolayısıyla böyle bir beklentinin gerçekleşmesi belirli bir stratejinin oluşturulmasıyla mümkün olabilecektir. Ayrıca küresel doğanların, küresel doğmayanlara göre ağ oluşturma mekanizmalarının daha net ve odaklı olduğunu söylemek mümkündür.

Uluslararasılaşmada geliştirilen ağların coğrafyalara göre dağıımına bakıldığında işletmelerin yakınlık kriterine göre ağ geliştirebildikleri görülmektedir. Bu çerçevede uzak pazar olan Amerika Kıtası'nda geliştirilen ağların son derece kısıtlı olmasının nedeni bu uzaklık olabilir. Iletişim açısından yeni medyaya dayalı ağları kullanma yetkinliğin zayıf olması bu tespiti güçlendirmektedir. Ayrıca coğrafyaya göre tercih edilen ağ kurma mekanizmaları da farklılıklar göstermektedir.

Genel olarak bakıldığında bulgular küçük ve orta ölçekli işletmelerin ağ kurma ve kullanma kabiliyetlerinin uluslararasılaşmada önemli olduğunu göstermektedir. Yerel müşterilerle, aile üyeleriyle olan ilişkiler ve hatta şans eseri karşılaşmalar işletmeye yabancı pazarlara ulaşma konusunda imkanlar yaratabilmektedir. Diğer bir ifade ile uluslararası fırsatlar çok çeşitli ağ destekli mekanizmalar aracılığıyla fark edilmektedir. Dolayısıyla yeni pazarlarda müşteri bulmaya çalışan işletmeler farklı ağ oluşturma mekanizmalarını bir araya getirmeyi başarabilirse, uluslararasılaşma sürecinde yabancı pazarlardaki fırsat aralığını da genişletmeyi başarabilecektir. Ayrıca işletmeler mevcut ve potansiyel ilişkilerini sürekli gözden geçirerek bu ilişkileri uluslararasılaşmada kullanılabilecek bir mekanizma haline getirebilirse, uluslararasılaşma sürecinin başlamasını da hızlandırabilecektir.

Araştırmanın en önemli kısıtı Ankara ilinden ihracat belgesi alan işletmelerin ele alınmasıdır. Bu anlamda farklı illerin de dahil olduğu bir çalışma ağ oluşturma mekanizmaları ile ilgili daha bütüncül ve karşılaştırmalı bir kavrayış sağlayabilecektir. Ayrıca örneklem sayısı sektörel odaklanmaya imkan vermemiştir. Dolayısıyla sektörlerin ağ oluşturma açısından farklılık gösterip göstermediği ortaya çıkarılamamıştır. Bu eksiklik bundan sonraki çalışmalar için bir araştırma konusu olabilir. Bununla birlikte işletmelerin uluslararasılaşmada farklı ağları kullanmalarının arkasındaki dinamiklerin ortaya çıkarılmasına yönelik bir çalışma çalışmamızın sonuçlarını güçlendirecek nitelikte olacaktır.

\section{Kaynaklar}

Akben, i. (2014). İşletmelerin uluslararasılaşma stratejileri: Kahramanmaraş işletmelerinde bir alan çalışması. KSÜ Sosyal Bilimler Dergisi, 11(2), 115-145.

Aldrich, H., \& Zimmer, C. (1986). Entrepreneurship through social networks. (Ed.) D. L. Sexton, \& R. W. Smilor, The art and science of entrepreneurship (ss. 3-23). Cambridge, MA: Ballinger.

Alimadadi, S., \& Pahlberg, C. (2014). A network view of MNC embeddedness in a politically uncertain market: The case of Turkey. Business and Politics, 16(2), 339-372.

Altıntaş, H. M., \& Özdemir, E. (2006). ihracat işletmelerinin uluslararasılaşması: Türkiye'de faaliyet gösteren Kobi'lere yönelik bir araştırma. Sosyal Bilimler Dergisi, 1, 183-204.

Altuntaş, G., Sözüer, A., \& Semerciöz, F. (2015). Uluslararası girişimcilik ile ihracat pazar performansı arasındaki ilişki: Türkiye'deki ihracatçı işletmeler örneği. Doğuş Üniversitesi Dergisi, 16(1), 65-78. 
Andersson, U., Forsgren, M., \& Holm, U. (2001). Subsidiary embeddedness and competence development in MNCs- A multi-level analysis. Organization Studies, 22(6), 1013-1034.

Andersson, S., \& Wictor, I. (2003). Innovative internationalisation in new firms: Born globals-the Swedish case. Journal of International Entrepreneurship, 1(3), 249-276.

Barney, J. (1991). Firm resources and sustained competitive advantage. Journal of Management, 17(1), 99-120.

Batas, S., \& Liu, L. (2013). The internationalization process of born global high technology SMEs: The moderating role of business and social networks. Suzhou-Silicon Valley-Beijing International Innovation Conference Innovation Conference (SIIC), (ss. 25-30). Suzhou, China.

Beğendik, B. (2017). Dimensions of entrepreneurial orientation and entrepreneur's characteristics that affect the internationalization process of Turkish born global firms. Gazi Üniversitesi iktisadi ve Idari Bilimler Fakültesi Dergisi, 19, 454-474.

Björkman, I., \& Kock, S. (1995). Social relationships and business networks: The case of western companies in China. International Business Review, 4(4), 519-535.

Borgatti, S. P., \& Lopez-Kidwell, V. (2014). Network theory. (Ed.) J. Scott, \& P. J. Carrington, The SAGE handbook of social network analysis (ss. 40-54). London: SAGE.

Burt, R. S. (1992). Structural holes: The social structure of competition. Cambridge MA: Harvard University Press.

Cannone, G., \& Ughetto, E. (2014). Born globals: A cross-country survey on high-tech start-ups. International Business Review, 23, 272-283.

Chandra, Y., \& Wilkinson, I. F. (2017). Firm internationalization from a network-centric complex-systems perspective. Journal of World Business, 52, 691-701.

Chetty, S., \& Holm, D. B. (2000). Internationalisation of small to medium-sized manufacturing firms: A network approach. International Business Review, 9, 77-93.

Ciravegna, L., Lopez, L., \& Kundu, S. (2014). Country of origin and network effects on internationalization: A comparative study of SMEs from an emerging and developed economy. Journal of Business Research, 67(5), 916-923.

Coviello, N. (2006). The network dynamics of international new venture. Journal of International Business Studies, 37(5), 713-731.

Coviello, N. E., \& Martin, K. A.-M. (1999). Internationalization of service SMEs: An integrated perspective from the engineering consulting sector. Journal of International Marketing, 7(4), 42-66.

Coviello, N. E., \& Munro, H. J. (1995). Growing the entrepreneurial firm: Networking for international market development. European Journal of Marketing, 29(7), 49-61.

Coviello, N., \& Munro, H. (1997). Network relationships and the internationalisation process of small software firms. International Business Review, 6(4), 361-386.

Çavuşgil, T. S., Knight , G., \& Üner, M. M. (2011). Türkiye'de küresel doğan işletmeler. Ankara: Detay Yayıncılık.

Ellis, P. (2000). Social ties and foreign market entry. Journal of International Business Studies, 31(3), 443-469.

Ellis, P. (2008). Social ties and international opportunity recognition. Hong Kong Polytechnic University.

Ellis, P., \& Pecotich, A. (2001). Social factors influencing export initiation in small and medium-sized enterprises. Journal of Marketing Research, 38(1), 119-130.

Forsgren, M., Holm, U., \& Johanson, J. (2005). Managing the embedded multinational: A business network view. Cheltenham: Edward Elgar.

Freeman, S., Edwards, R., \& Schroder, B. (2006). How smaller born-global firms use networks and alliances to overcome constraints to rapid internationalization. Journal of International Marketing, 14(3), 33-63.

Ge, G. L., \& Wang, H. Q. (2013). The impact of network relationships on internationalization process: An empirical study of Chinese private enterprises. Asia Pacific Journal of Management, 30(4), 1169-1189.

Gittins, T., Lang, R., \& Sass, M. (2015). The effect of return migration driven social capital on SME internationalisation: a comparative case study of IT sector entrepreneurs in Central and Eastern Europe. Review of Managerial Science, 9, 385-409.

Granovetter, M. (1973). The strength of weak ties. American Journal of Sociology, 78(6), 1360-1380.

Hansen, M. T. (1999). The search-transfer problem: The role of weak ties in sharing knowledge across organization subunits. Administrative Science Quarterly, 44(1), 82-111. 
Hohenthal, J., Johanson, J., \& Johanson, M. (2014). Network knowledge and business-relationship value in the foreign market. International, 23, 4-19.

Kalyoncuoğlu, S., \& Üner, M. M. (2010). Küresel doğan işletme kavramı ve işletmelerin küresel doğmasına etki eden kurucu/üst düzey yönetici özellikleri üzerine karşılaştırmalı bir araştırma. Gazi Üniversitesi iktisadi ve Idari Bilimler Fakültesi Dergisi, 12(3), 1-42.

Kanat, S. (2016). Internationalization process of Turkish clothing sector. Tekstil ve Konfeksiyon, 26(1), 3-11.

Kontinen, T., \& Ojala, A. (2011). Network ties in the international opportunity recognition of family SMEs. International Business Review, 20, 440-453.

Laufs, K., \& Schwens, C. (2014). Foreign market entry mode choice of small and medium-sized enterprises: A systematic review and future research agenda. International Business Review, 23, 1109-1126.

Lechner, C., \& Dowling, M. (2003). Firm networks: External relationships as sources for the growth and competitiveness of entrepreneurial firms. Entrepreneurship \& Regional Development, 15(1), 1-26.

Lindstrand, A., \& Hånell, S. M. (2017). International and market-specific social capital effects on international opportunity exploitation in the internationalization process. Journal of World Business, 52, 653-663.

Loane, S., Bell, J., \& McNaughton, R. (2007). A cross-national study on the impact of management teams on the rapid internationalization of small firms. Journal of World Business, 42(4), 489-504.

Maoz, Z. (2011). Networks of Nations. The evolution, structure, and impact of international networks, 1816-2001. New York: Cambridge University Press.

McDougall, P. P., Shane, S., \& Oviatt, B. M. (1994). Explaining the formation of international new. Journal of Business Venturing, 9(6), 469-487.

McEvily, B., \& Zaheer, A. (1999). Bridging ties: A source of firm heterogeneity in competitive capabilities. Strategic Management and Entrepreneurship, 20(12), 1133-1156.

Moen, $\varnothing$. (2002). The born globals: A new generation of small European exporters. International Marketing Review, 19(2), 156-175.

O'Gorman, C., \& Evers, N. (2011). Network intermediaries in the internationalisation of new firms in peripheral regions. International Marketing Review, 28(4), 340-364.

Ojala, A. (2009). Internationalization of knowledge-intensive SMEs: The role of network relationships in the entry to a psychically distant market. International Business Review, 18(1), 50-59.

Oparaocha, G. O. (2015). SMEs and international entrepreneurship: An institutional network perspective. International Business Review, 24(5), 861-873.

Oviatt, B. M., \& McDougall, P. P. (2005). Defining international entrepreneurship and modeling the speed of internationalization. Entrepreneurship Theory \& Practice, 29(5), 537-553.

Paniagua, J., Korzynski, P., \& Mas-Tur, A. (2017). Crossing borders with social media: Online social networks and FDI. European Management Journal, 35(3), 314-326.

Pescosolido, B. A. (2007). The sociology of social networks. (Ed.) C. D. Bryant, \& D. L. Peck, 21st century: A reference book (ss. 208-217). Thousand Oaks: SAGE .

Rowley, T., Behrens, D., \& Krackhardt, D. (2000). Redundant governance structures: An analysis of structural and relational embeddedness in the steel and semiconductor industries. Strategic Management Journal, 21(3), 369386.

Senik, Z. C., Isa, R. M., Scott-Ladd, B., \& Entrekin, L. (2010). Influential factors for SME internationalization: Evidence from Malaysia. International Journal of Economics and Management, 4(2), 285-304.

Senik, Z. C., Scott-Ladd, B., Entrekin, L., \& Adham, K. A. (2011). Networking and internationalization of SMEs in emerging economies. Journal of International Entrepreneurship, 9, 259-281.

Sharma, D. D., \& Johanson, J. (1987). Technical consultancy in internationalisation. International Marketing Review, 4(4), 20-29.

Singh, R. P. (2000). Entrepreneurial opportunity recognition through social networks. New York: Garland Publishing.

Şahin, K. T., Mert, K., \& Kaplan , T. (2015). Global dinamik yeteneklerin uluslararasılaşma sürecinde kullanımı: İşletme grupları perspektifi. Ankara Üniversitesi SBF Dergisi, 70(4), 931-956.

Tabares, A., Alvarez, C., \& Urbano, D. (2015). Born globals from the resource-based theory: A case study in Colombia. Journal of Technology Management \& Innovation, 10(2), 154-165. 
Teece, D. J., Pisano, G., \& Shuen, A. (1997). Dynamic capabilities and strategic management. Strategic Management Journal, 18(7), 509-533.

Türkiye Cumhuriyeti Ekonomi Bakanlığı. İhracat Destekleri: http://www.ekonomi.gov.tr (Erişim tarihi 01/03/2018)

Udomkit, N., \& Schreier, C. (2017). Tie the ties: The significance of the binding networks in SMEs' internationalization process. Journal of Asia-Pacific Business, 18(1), 4-20.

Wang, C., Hong, J., Kafouros, M., \& Wright, M. (2012). Exploring the role of government involvement in outward FDI from emerging economies. Journal of International Business Studies, 43(7), 655-676.

Wasserman, S., \& Faust, K. (1994). Social network analysis: Method and applications. Cambridge: Cambridge University Press.

Yli-Renko, H., Autio, E., \& Tontti, V. (2002). Social capital, knowledge, and the international growth of technology-based new firms. International Business Review, 11(3), 279-304.

Zain, M., \& Ng, S. I. (2006). The impacts of network relationships on SMEs' internationalization process. Thunderbird International Business Review, 48(2), 183-205.

Zarei, B., Nasseri, H., \& Tajeddin, M. (2011). Best practice network business model for internationalization of small and medium enterprises. Journal of International Entrepreneurship, 9(4), 299-315. 